\title{
ИСтория БЕлАРССи
}

\section{Г ІсторЫЯ БеЛАРУСІ}

\section{B ELARUSIAN HISTORY}

\section{АЕНЬГИ «НА ВОЗНАГРАЖАЕНИЕ РАБОТ И УБЫТКОВ» АЯЯ МИНСКОГО СТАРОСТЫ КШИШТОФА ЗАВИШИ И ЕГО СПОР С АИТОВСКИМИ ПОАСКАРБИЯМИ В ПЕРВОЙ ЧЕТВЕРТИ ХVIII В.}

\author{
А. ШКРИПЕЦ ${ }^{1)}$ \\ ${ }^{1)}$ Институт истории Силезского университета в Катовице, \\ ул. Банковая, 11, 40-007, г. Катовице, Польша
}

Рассматриваются усилия минского старосты Кшиштофа Завиши, направленные на получение денег, обещанных ему королем Речи Посполитой Августом II в качестве вознаграждения за верность и оказанные монарху услуги. Цель статьи - показать специфику политических отношений в Великом княжестве Литовском и Речи Посполитой на рубеже XVII-XVIII вв. на примере конфликта вокруг выплаты денег, которые Август II обещал Завише. Материал основан на архивных источниках и затрагивает тему, важную для истории бывших земель Великого княжества Литовского.

Ключевые слова: минский староста Кшиштоф Завиша; выборы короля Августа II; политические отношения; Великое княжество Литовское; Речь Посполитая; XVII-XVIII вв.

\section{Образец цитирования:}

Шкрипец А. Деньги «на вознаграждение работ и убытков» для минского старосты Кшиштофа Завиши и его спор с литовскими подскарбиями в первой четверти XVIII в. Журнал Белорусского государственного университета. История. 2020;1:30-37.

https://doi.org/10.33581/2520-6338-2020-1-30-37.
For citation:

Skrzypietz A. Money «for the remuneration of works and losses» for Krzysztof Zawisza the warden of Minsk and his dispute with the Lithuanian treasury in the first quarter of the $18^{\text {th }}$ century. Journal of the Belarusian State University. History. 2020;1:30-37. Russian.

https://doi.org/10.33581/2520-6338-2020-1-30-37.

\section{Ав тор:}

Александра Шкрипец - доктор исторических наук; преподаватель.
Author:

Aleksandra Skrzypietz, doctor of science (history); lecturer. jaskrzyp@interia.pl 


\title{
ГРОШЫ «НА ЎЗНАГАРОАЖАННЕ РАБОТ І СТРАТ» АЛЯ МІНСКАГА СТАРАСТЫ КШЫШТАФА ЗАВІШЫ І ЯГО СПРЭЧКА 3 АІТОЎСКІМІ ПААСКАРБІЯМІ Ў ПЕРШАЙ ЧВЭРЦІ XVIII СТ.
}

\author{
А. ШКРЫПЕЦ ${ }^{1 *}$ \\ 1* Інстытут гісторыі Сілезскага ўніверсітэта ў Катавіцах, \\ вул. Банкаўская, 11, 40-007, г. Катавіцы, Польшча
}

Разглядаюцца намаганні мінскага старасты Кшыштафа Завішы, накіраваныя на атрыманне грошай, абяцаных яму каралём Рэчы Паспалітай Аўгустам II у якасці ўзнагароджання за вернасць і аказаныя манарху паслугі. Мэта артыкула - паказаць спецыфіку палітычных адносін у Вялікім Княстве Літоўскім і Рэчы Паспалітай на мяжы XVII-XVIII стст. на прыкладзе канфлікту вакол выплаты грошай, якія Аўгуст II абяцаў Завішу. Матэрыял заснаваны на архіўных крыніцах і закранае тэму, важную для гісторыі былых зямель Вялікага Княства Літоўскага.

Ключавыя словы: мінскі стараста Кшыштаф Завіша; выбары караля Аўгуста I; палітычныя адносіны; Вялікае Княства Літоўскае; Рэч Паспалітая; XVII-XVIII стст.

\section{MONEY «FOR THE REMUNERATION OF WORKS AND LOSSES» FOR KRZYSZTOF ZAWISZA THE WARDEN OF MINSK AND HIS DISPUTE WITH THE LITHUANIAN TREASURY IN THE FIRST QUARTER OF THE $18^{\text {th }}$ CENTURY}

\author{
A. SKRZYPIETZ \\ ${ }^{\mathrm{a}}$ Institute of History, University of Silesia in Katowice, 11 Bankowa Street, Katowice 40-007, Poland
}

The article presents the efforts of Krzysztof Zawisza the warden of Minsk to receive the money promised to him by August II. It was a gift from the king to reward the loyalty and service that Zawisza gave to the monarch. It took over 20 years to get the money because Michal Kociell the Lithuanian treasurer was the personal enemy of Zawisza. Nevertheless some part of the promised sum went to his hands. The purpose of the article is to show the conflict over the payment of money, and in this example to show the specificity of political relations in the Grand Duchy of Lithuania and the Polish-Lithuanian Commonwealth at the turn of the $17^{\text {th }}$ and $18^{\text {th }}$ centuries. The article is based on archival materials and raises an important topic for the history of the former lands of the Grand Duchy of Lithuania.

Keywords: Minsk warden Krzysztof Zawisza; election of king August II; political relations; the Grand Duchy of Lithuania; the Polish-Lithuanian Commonwealth; $17^{\text {th }}-18^{\text {th }}$ centuries.

\section{Введение}

Кшиштоф Станислав Завиша, староста минский и чечерский, «имел столько положительных качеств ума, которые, если и не формируют большинство влиятельных людей, то, по крайней мере, ярко их выделяют в прошлом и всегда присущи крупным историческим личностям» ${ }^{1}[1, \mathrm{~s}$. II]. Он был сыном великого литовского писаря Андрея Казимира Завиши и Александры Огинской. После смерти родителей и старших братьев о нем заботился дядя, канцлер ВКЛ Мартиан Александр Огинский, под крылом которого Кшиштоф Завиша начал политическую карьеру. Он многократно избирался депутатом на сеймы, бывал также маршалком сейма, входил в состав посольства, напрвленного в Москву в 1686 г.

Сестра Кшиштофа Анна вышла замуж за Мартина Михаила Кришпин-Киршенштейна - великого литовского подстолия $[1, \mathrm{s.}$ V]. Родство с Огинскими и своячничество с Кришпин-Киршенштейнами связывали Завишу с врагами Сапегов и литовскими республиканцами. Однако это не помешало ему жениться на Терезе Тышкевич - внучке великого литовского гетмана Павла Яна Сапеги по материнской линии. Кшиштоф Завиша стремился поддерживать дружеские отношения с семьей жены. Так, Завиши попросили стать крестными родителями своих детей великого литовского гетмана Казимира Яна Сапегу (кузен Терезы) и его супругу [1, s. XII].

Цель статьи - показать специфику политических отношений в Великом княжестве Литовском и Речи Посполитой на рубеже XVII-XVIII вв. на примере конфликта вокруг выплаты денег, которые король Речи Посполитой Август II обещал Завише. Статья основана на архивных материалах.

\footnotetext{
${ }^{1}$ Здесь и далее перевод наш. - А. Ш.
} 


\section{Основная часть}

После смерти Яна III Собеского Сапеги приложили большие усилия для увеличения числа сторонников своего кандидата на престол Франсуа-Луи де Бурбона, принца де Конти. Кшиштоф Завиша склонялся к тому, чтобы присоединиться к французскому лагерю, 2 марта 1697 г. он встретился с литовским подскарбием Бенедиктом Павлом Сапегой, чтобы побеседовать «по вопросам разного понимания моего дома и вашей милости о выборе будущего короля», но соглашение между ними не было достигнуто [1, s. 50].

«Мы разъехались среди взаимных вежливостей», - подытожил эти беседы минский староста $[1$, s. 50]. Позже, также безрезультатно, Сапега старался склонить на свою сторону Кришпин-Киршенштейнов, но они только для вида поддались его убеждениям и даже заключили 23 ноября 1696 г. соответствующее соглашение. Однако во время выборов как Кришпин-Киршенштейны, так и Завиши поддержали саксонского курфюрста [2, s. 586].

Кшиштоф Завиша был избран депутатом в конвокационный, а затем избирательный сейм, где открыто присоединился к сторонникам республики. На минском сеймике он поклялся «защищать права и свободу родины» [3, p. 231-242]. Выполняя это обещание, минский староста потребовал выравнивания прав. В этот момент он вступил в открытый конфликт с Сапегами. В своих дневниках Завиша сетовал на то, что в отместку великий литовский гетман Казимир Сапега воспринял это как оскорбление, словно это навредило бы его власти, «наступил на имущество мое» $[1$, s. 24].

Минский староста вместе с витебским каштеляном Михаилом Казимиром Коцеллом 13 мая 1697 г. прибыл в столицу [1, s. 51]. На одной из первых сессий сейма, 17 мая, Завиша от своего имени и от имени литовцев жаловался на несоответствующие квартиры, которые им предоставлены ${ }^{2}$. Начало сейма проходило в обсуждении формальноправовых споров, предусматривающих продление заседаний [4, s. 34]. Завиша заявил о проблемах магнатских свит ${ }^{3}$, а когда его обвинили в инфамии, «начал рваться к сабле» ${ }^{4}$. Минская шляхта встала на сторону старосты ${ }^{5}$, что привело к беспорядку ${ }^{6}$. Завиша вспоминал, что несколько раз доходило до рукоприкладства [1, s. 51]. Вопрос больших магнатских свит был позже поднят и другими литовскими депутатами. Наконец, 21 мая минский староста высказался относительно самого острого вопроса, а именно выбора маршалка. Он четко понимал, что заседания тянутся уже неделю, лишенные важнейшего лица - руководителя сейма. Во время выборов маршалка 15 июня Завиша от имени Минского повета отдал 200 черточек за коронного подкомория Казимира Людвика Белинского, сторонника француза ${ }^{7}$. В ходе дальнейших заседаний сейма Кшиштоф Завиша вместе с мстиславским хорунжим Мартианом Домиником Воловичем и брестским подкоморием Людвиком Поцеем пытались добиться выравнивания прав ${ }^{8}$. Вопросы выбора маршалка и выравнивания прав вызвали споры среди представителей большинства земель Великого княжества Литовского. Однако в итоге, вопреки стараниям и надеждам Сапегов, выравнивание прав было одобрено. Сперва была назначена комиссия по его подготовке, а затем приняли соответствующий документ ${ }^{9}$. Завиша хвалился, что поднятие вопроса выравнивания прав Литовского княжества с Короной - его заслуга. Это еще больше возмутило гетмана и сапежинский дом $[1, \mathrm{s.} 25]$.

Что касается выборов короля, Завиша поддержал кандидатуру Фридриха Августа Веттина. Минский староста был откомандирован в представительство, следовавшее на встречу с новым главой. Саксонский курфюрст радушно принял гостей в Тарновских Горах. Пирушки, гулянки, банкеты, вечеринки и «игра со стрельбой и дугой», организованные курфюрстом, чрезвычайно понравились минскому старосте, так как была «роскошь в еде и напитках» [1, s. XII, 52]. O короле Завиша будет писать всегда положительно, особенно в контексте банкетов, в которых еще не раз примет участие ${ }^{10}$.

B Volumina legum при выборе короля неоднократно упоминается фамилия минского старосты. Он подписал Coequatio iurium una cum ordinatione iudiciorium tribunalitiorum et repartitione locationeque exercituum M.D. Lit. [5, s. 421] и был избран депутатом ad pacta conventa по Минскому воеводству. Его фамилия числится в Suffragia воеводств (Suffragia woiewództwy ziem koronnych y Wielkiego Księstwa Litewskiego zgodnie do nayiaśnieyszego Augusta II obranego króla polskiego y W. X. Lit. dane między Warszawą i Wola, dnia 27 miesiąca

${ }^{2}$ Biblioteka Czartoryskich (dalej - BCzart.). Ms. 521. S. 521.

${ }^{3}$ Dyaryusz elekcyi w Warszawie 15 mai 1697 roku zaczętey // BCzart. Ms. 188. S. 43.

${ }^{4}$ BCzart. Ms. 521. S. 527.

${ }^{5}$ Dyaryusz elekcyi w Warszawie 15 mai 1697 roku zaczętey // BCzart. Ms. 188. S. 43.

${ }^{6}$ Dyaryusz seymu w Warszawie 15 mai 1697 roku zaczętey // Ibid. S. 549.

${ }^{7}$ Dyaryusz elekcyi 15 maja 1697 roku zaczętej // Ibid. Ms. 189. S. 44, 45, 56, 109.

${ }^{8}$ Dyaryusz seymu 15 maja 1697 roku zaczętej // Ibid. Ms. 189. S. 551.

${ }^{9}$ Ibid. S. $559,563$.

${ }^{10}$ Dyaryusz negocyacyi jaśnie wielmożnych Ichmościów Panów Posłów od Rzeczpospolitey do Króla Jegomości obranego Fryderyka Augusta cum denuntiatione wyprawionych z Warszawy 15 lipca 1697 // BCzart. Starodruk 60887 III. K. F-H 3 ; Zawisza K. Pamiętniki Krzysztofa Zawiszy, wojewody mińskiego (1666-1721), wydane z oryginalnego rękopismu i opatrzone przypiskami przez Juliana Bartoszewicza. Warszawa, 1862. S. 52. 
czerwca y przy poparciu wolney elekcyi iego [5, s. 458]) от 27 июня 1697 г., но отсутствует в Oznaymienie новоизбранного короля (Oznaymienie króla nowo obranego na seymie walnym elekcyi między Warszawa a Wola die 27 iunij anno 1697 [5, s. 459-462]), также от 27 июня 1697 г. И даже если последний документ датирован задним числом, отсутствие фамилии минского старосты не объясняется тем, что он уже был в пути на встречу с королем, поскольку в этом же документе значится фамилия Яна Станислава Яблоновского, который следовал в Силезию. И, наконец, записано, что Ян (так в оригинале) Завиша, минский староста, избран королевским резидентом, хотя обычно довольно скрупулезный в своих дневниковых записях Завиша не подтверждает этого. Так что, вероятно, была допущена ошибка в имени ${ }^{11}$.

На коронационном сейме Кшиштоф Завиша по воле монарха получил булаву маршалка, так как «хорошо сыграл свою роль» $[1, \mathrm{~s}$. XIII] и действительно произвел впечатление на короля своим поведением. По всей видимости, Август II был на стороне республиканцев. Минского старосту он поддерживал как человека, косвенно лавирующего между лагерями Сапегов и шляхты. Монаршее расположение и поддержка двора были на руку Завише, поскольку из-за напряженной ситуации в Литве гнев Сапегов в отношении него усиливался. Однако они ничего не могли сделать Завише: на его стороне была «влиятельная протекция короля» [1, s. 25]. В 1698 г. по просьбе двора минский староста пытался урегулировать конфликты в Литве. В знак благодарности за оказанную услугу он получил должность великого литовского писаря. При этом король пообещал ему малую литовскую печать $[1$, s. 58]. Однако впоследствии, когда Август II лично приехал в Литву с целью снискать расположение республиканцев, он решил отдать малую литовскую печать Михаилу Коцеллу, что стало поводом для возникновения недоразумений между двумя литвинами [6, s. 92-93].

В это же время Завиша старался уладить споры между Сапегами. Сначала он попытался достичь соглашения с великим литовским конюшим Михаилом Франтишком Сапегой, и, когда получилось, считал этот путь проторенным. Но проблемы с великим гетманом Казимиром и великим подскарбием Бенедиктом не удалось решить полностью. Главы сапежинского дома все время были в обиде, пробовали даже захватить его блага. Сблизившись с Сапегами, Завиша навлек на себя недовольство шляхты [1, s. 57].

До начала ожидаемых заседаний пацификационного сейма Завиша стал депутатом в Вилькомире [1, s. 68]. После долгих формальных споров он передал булаву маршалка Станиславу Антонию
Щуке. Прежде чем это произошло, Завиша пытался опровергнуть обвинения в отношении короля в продлении пребывания саксонских войск в Речи Посполитой. Ему была нанесена большая обида, а затем начался спор за литовское подканцлерство. Несмотря на поддержку примаса Михаила Стефана Радзиевского и большинства сенаторов, Завиша не был удостоен печати. Не получил ее и Михаил Коцелл, протежируемый королем. Не помогли ни письма, отправляемые в литовские сеймики, ни предварительно подписанная Августом II привилегия. Победителем оказался Станислав Щука под аплодисменты депутатской палаты [1, s. 69; 7, s. 135, 170-171]. Возможно, монарх решил не доверять такую важную должность минскому старосте, считая его человеком с неустойчивыми политическими взглядами, что пока проявлялось в противоречивых отношениях с Сапегами.

Поражение в борьбе за должность не помешало Завише выпить с королем, мальборским воеводой Яном Ежи Пшебендовским, литовским подканцлером Каролем Станиславом Радзивиллом и жемайтским каштеляном Вием Евстафием Гротгусом, о чем минский староста написал: «С королем мы выпили до сытности, вина, потом водку выпивая (дубль анис), который с королем по пять раз мы выпили» [1, s. 69]. Безусловно, Завиша старался наладить связи с важнейшими лицами в Речи Посполитой. Возможно, в утешение после неполучения печати, а быть может, за многочисленные заслуги Завиши Август II обещал ему сумму в 4 тыс. талеров как «вознаграждение работ и убытков», вакантную должность и дальнейшие милости $[1$, s. 69].

Во введении изданных Юлианом Бартошевичем «Дневников Кшиштофа Завиши» можно заметить ошибку, скорее всего, опечатку: написано, что тогда Завиша получил 40 тыс. талеров. Это не соответствует ни тексту «Дневников» $[1$, s. 69], ни квитанциям, хранимым в Научной библиотеке Польской академии искусств и Польской академии наук в Кракове. Там есть папка с документами, представляющими споры между Кшиштофом Завишей и литовскими подскарбиями, достигшие апогея и частично разрешенные, когда эту должность занимал Михаил Коцелл. Конфликт начался именно на пацификационном сейме в 1699 г., а последняя квитанция, содержащаяся в рассматриваемом сборнике, датируется 1718 г.

Первая из квитанций, выставленная 27 июля 1699 г. в Варшаве, велит литовскому подскарбию, а в то время эту должность занимал Бенедикт Сапега, выплатить Кшиштофу Завише из литовской казны 4 тыс. талеров, полученных по новым повышенным пошлинам ${ }^{12}$. Речь идет о деньгах, взима-

\footnotetext{
${ }^{11}$ Deputacya na rezydencyą // Volumina legum. Przedruk zbioru praw staraniem XX. Pijarów w Warszawe, od roku 1732 do roku 1782, wydanego. T. 5. Petersburg, 1860. S. 463.

${ }^{12}$ Zalecenie wypłaty 4 tysięcy talarów bitych Krzysztofowi Zawiszy, Warszawa, 27.07.1699 // Biblioteka PAU i PAN w Krakowie (dalej - BPAN). Ms. 5915. K. 1 r. - 1 v.
} 
емых в казну с импортных товаров [8, s. 73]. Среди прочих документ подписали витебский каштелян Михаил Коцелл, виленский епископ Константин Казимир Бжостовский, великий литовский гетман и виленский воевода Казимир Сапега, а также полоцкий воевода Доминик Михаил Слушка ${ }^{13}$.

На обратной стороне квитанции имеется пометка от 16 февраля 1712 г. о включении ее в дела трибунала, подписанная литовским канцлером Каролем Станиславом Радзивиллом. Еще одна идентичная пометка от 3 июня 1713 г. подписана брестским воеводой Владиславом Юзафатом Сапегой. Оба в упомянутых годах являлись маршалками Скарбового трибунала. При этом от имени Завиши действовал патрон Якуб Чернявский, упицкий городничий ${ }^{14}$.

Сумма, обещанная Завише, не была выплачена, а он сам 7 июля 1700 г. собрался совершить паломничество в Рим. Якобы это было его давним желанием, но с политической точки зрения время минский староста выбрал наиболее подходящее, избежав потрясших Литву конфликтов, когда началась борьба Сапегов с республиканцами. В 1700 г. Завиша старался не вовлекаться в общественные дела: «Этот год я прожил своей частной жизнью, не присоединившись ни к какой партии, за виленским и гродненским съездами, а также сеймиками и сеймом я не следил, издали я прислушивался к несчастьям Речи Посполитой» [1, s. 26].

Тему выплаты обещанных денег Завиша поднимал в своей переписке один раз: в декабре 1700 г. он написал канцлеру Каролю Станиславу Радзивиллу, что до сих пор их не получил ${ }^{15}$.

Когда в марте 1701 г. Завиша вернулся в страну, его отношения с Сапегами улучшились. Не время было держать друг на друга старые обиды. Гетман и подскарбий искали в лагере шведского короля союзников против «новой Речи Посполитой Литовской», и Завиша вместе с ними перешел на сторону Карла XII [9, s. 93]. Оставшуюся часть года минский староста «прожил частной жизнью» [1, s. 26]. Между тем Завиша убил свояка ${ }^{16}$, за что его возненавидела шляхта. Суда он избежал благодаря хорошим отношениям со шведами. Будучи свободным от общественных обязанностей, Завиша интересовался деньгами, причитавшимися ему за заслуги перед королем, которого он только что предал.

В связи с этим 26 сентября 1701 г. в Гродно была выставлена вторая квитанция, подтверждающая недоимки государственной казны в отношении Кшиштофа Завиши в размере 4 тыс. талеров. Ука- занную сумму ему должен был выплатить Михаил Коцелл, сборщик пошлин в Литве ${ }^{17}$, занимавший эту должность вместе с Николаем Огинским. Среди прочих документ подписали Коцелл и виленский епископ Константин Бжостовский. В предыдущей квитанции от 1699 г., внесенной в трибунальские акты, стоят те же даты и подписи ${ }^{18}$.

На наш взгляд, вторую квитанцию следует трактовать как проявление борьбы Сапегов, в то время друзей Завиши, с Коцеллом. Сапежинская сторона стремилась привлечь последнего к ответственности за совершенные финансовые злоупотребления [10]. Все соглашения, заключенные между Сапегами и Коцеллом, были расторгнуты. Конечно, спор являлся более обширным и сложным, а обе стороны старались добиться помощи посторонних: Сапеги - шведов, а Коцелл - Августа II.

В этом же году 27 октября на гродненской сессии Завише подтвердили, что обязательство не было исполнено ни подскарбием, ни сборщиком пошлин. Коцеллу еще раз велели подчиниться распоряжению трибунала и выплатить указанную сумму $^{19}$, однако безрезультатно.

Спор между Завишей и Коцеллом обострился в 1702 г. Минский староста оставался в лучших отношениях с Сапегами, чем с Августом II. В мае того же года по инициативе Завиши в Вильне собрался трибунал $[1$, s. 26], но из-за отсутствия кворума его пришлось распустить. В свою очередь, Коцелл тоже созвал сессию трибунала и при этом добился успеха [2, s. 44].

В 1703 г. шведское преимущество обеспечило победу Сапегам. Коцелла и Огинского лишили контроля за казной. Им было велено отчитаться за потраченные деньги. Контроль за казной перешел к Людвику Поцею и Мартиану Воловичу. И хотя они были представителями республиканцев, но на тот момент представляли меньшую угрозу, к тому же Поцей опередил Коцелла в борьбе за литовское казначейство [1, s. 113; 2, s. 44; 11, s. 40].

Завиша пытался укрепить свои отношения с Поцеем, а также с Кришпин-Киршенштейнами, встречался с ними, о чем признавался в мемуарах: «...я бывал, шутил с ними, но аккуратно» [1, s. 113]. В то же время минский староста приглядывался к наиболее безопасному политическому варианту: сблизился с Августом II, но не прекращал содействовать Станиславу Лещинскому. Веттин разоблачил эту игру, но простил Завишу, возможно рассчитывая на то, что его обширные контакты смогут еще когданибудь пригодиться [1, s. 113-115, XXV].

\footnotetext{
${ }^{13}$ Zalecenie wypłaty 4 tysięcy talarów bitych Krzysztofowi Zawiszy, Warszawa, 27.07.1699 //BPAN. Ms. 5915. K. 1 r. - 1 v.

${ }^{14}$ Ibid.

${ }^{15}$ Krzysztof Zawisza do Stanisława Radziwiłła, Rzym, 17.12.1700 // Arch. Gł. Akt Daw., Arch. Radziwiłłów V. Ms. 18581. S. 30.

${ }^{16}$ Анна, сводная сестра Кшиштофа Завиши, вышла замуж за простого дворянина, который якобы руководствовался не любовью, а расчетом. Завиша не мог терпеть это несоответствие. Он вторгся в отношения пары, забрал сестру и заключил в тюрьму ее мужа, сбежавшего из дома, «судил» и убил его [1, s. XXI].

${ }^{17}$ Potwierdzenie zalecenia wypłaty 4 tysięcy talarów, [b. m.], 27.10.1701 // BPAN. Ms. 5915. S. 3 r.

${ }^{18}$ Ibid.

${ }^{19}$ Nakaz kierowany do Michała Kociełła wypłacenia sumy zaległej Krzysztofowi Zawiszy, Wilno, 27.10.1701 // Ibid. K. 3 r.
} 
В 1704 г. Завиша начал управлять сапежинской армией, когда великий гетман Казимир Сапега отправился в Клайпеду. Таким образом, минский староста очередной раз встал на шведскую сторону [2, s. 44]. В 1709 г., чтобы поощрить его верность, Станислав Лещинский обещал Завише любую вакантную должность, повторяя тем самым маневр Августа II в 1699 г. [1, s. 144].

В конце января 1712 г. Завиша прибыл на Скарбовый трибунал, где еще раз поднял вопрос о своих деньгах. Маршалком судов в то время являлся канцлер Кароль Станислав Радзивилл. В итоге 6 февраля был составлен документ, рекомендовавший внести в материалы дела, что Завиша причитающихся ему денег не получил. Дело в очередной раз было направлено Коцеллу. Аналогичное занесение предлагалось сделать в материалы дела от 1699 и 1701 гг. Под документом имеется более поздняя запись от 1713 г. с подписью Владислава Сапеги. Помимо прочего, проставлена печать Кароля Станислава Радзивилла. Наконец, 11 февраля 1712 г. комиссарами Скарбового трибунала, назначенными Варшавской вальной радой, был составлен приказ Михаилу Коцеллу о незамедлительной выплате минскому старосте должной ему суммы. Его подписали Кароль Станислав Радзивилл и Константин Бжостовский. Этот документ также содержит запись от 1713 г. с подписью Владислава Сапеги, брестского воеводы ${ }^{20}$.

В 1712 г. Михаил Коцелл снова вступил в открытый конфликт с Сапегами и Огинскими. Выполняя функцию литовского подскарбия с 1710 г., Коцелл усложнял королю управление столовым имением в Великом княжестве Литовском. Кроме того, он был известен многочисленными грабежами и насилием по отношению к шляхте [12, s. 223-225]. Его даже арестовали, а дело направили в суд. Однако, несмотря на обвинительный приговор, Коцелл остался на свободе [8, s. 109]. В это время Завиша немного ограничил свою политическую деятельность: был избран депутатом на сейм 1712 г., но на первую сессию не явился, а на осеннюю планировал отправить сына Игнатия. Тем не менее минский староста постоянно следил за своими финансовыми интересами. Прежде всего он стремился укрепить отношения с Мартианом Огинским, в то время трибунальским маршалком. А 6 ноября 1712 г. торжественно и с небывалой роскошью принимал у себя в гостях членов трибунала [1, s. 157].

В 1713 г. Завиша участвовал в заседании трибунала. Избранный маршалком, отдал свою булаву «великому другу» брестскому воеводе Владиславу Сапеге [1, s. 157], желая затронуть дело о выплате обещанных денег и рассчитывая на положительное его рассмотрение. Дело набрало ход, и 20 января 1713 г. в Вильне Завиша расписался в получении 1 тыс. талеров от Коцелла. По всей вероятности, это была первая выплата, свидетельствовавшая о готовности подскарбия пойти на уступки, что мотивировало минского старосту к более активным действиям: 6 апреля он потребовал занесения в трибунальские книги своих претензий по отношению к литовскому подскарбию о задержках в выплате 4 тыс. талеров, а 3 июня того же года представитель Завиши Якуб Черневский еще раз предъявил судьям поручение выплаты от 1699 г. и ходатайствовал о включении его в главные книги трибунала. Дата 3 июня 1713 г. имеется в шести документах. Три из них - это подлинники с подписями и печатями трибунала, каждый написан разной рукой, а три других - копии предыдущих. При этом только на одном подлиннике имеется подтверждение получения Завишей 1 тыс. талеров. Этот документ содержит пометку, что 2 октября 1713 г. он приобщен к материалам дела ${ }^{21}$.

В этом же году Завиша был отправлен к королю в Варшаву для «эвакуации саксонцев из Литвы» [1, s. 159]. На самом деле он ничего не сделал для княжества, но позаботился о своих интересах и интересах членов трибунала, добившись для них освобождения от налогов и приняв присягу на верность сандомирской конфедерации. Позже, в 1714 г., он писал: «Этот год я начал в согласии с паном королем Августом, курфюрстом Саксонии, по сути, я помирился с ним» [1, s. 30]. Тем временем Людвик Поцей и Огинские наладили связь с Петром I. Однако царь не поддержал их замыслов открыто, но проявил к ним свое расположение [12, s. 209].

Желая привлечь на свою сторону Завишу, 1 января 1716 г. король отправил Коцеллу письмо с приказом выплатить задолженную сумму 4 тыс. талеров $^{22}$. Но, несмотря на вмешательство монарха, минский староста, скорее всего, так и не получил никаких денег, по крайней мере, этому нет доказательств. В сентябре того же года Завиша снова гостил в Варшаве, ведя переговоры с представителем царя Григорием Долгоруким [12, s. 238].

Решив добиться своих денег любой ценой, минский староста попытался пойти другим путем: постарался, чтобы маршал литовской конфедерации Кшиштоф Франтишек Сулистровский написал королю письмо с просьбой приказать Коцеллу выплатить обещанную Завише сумму. Письмо было отправлено 11 ноября 1716 г., но и это усилие не дало результатов ${ }^{23}$.

Наконец, 8 января 1717 г. представитель минского старосты Казимир Тышкевич подал все жало-

\footnotetext{
${ }^{20}$ Dokumenty Trybunału Skarbowego, Wilno, 6.02.1712 // BPAN. Ms. 5915. K. 5 r. -7 v. $23 \mathrm{v}$.

${ }^{21}$ Wypisy z Xiąg Głównych Trybunału Wielkiego Xięstwa Litewskiego, Wilno, 4.02.1713, 7.04.1713, 3.07.1713 // Ibid. K. 7 v., 9 r. -

${ }^{22}$ August II do Krzysztofa Zawiszy, Warszawa, 1.01.1701 // Ibid.

${ }^{23}$ Krzysztof Franciszek Sulistrowski do Michała Kociełła, Brześć, 11.11.1716 // Ibid. K. 27 r.
} 
бы Кшиштофа Завиши на Михаила Коцелла в гродненский суд. Помимо этого, Тышкевич пробовал убедить подскарбия, предъявляя ему очередное письмо короля с приказом выплаты причитающейся Завише суммы. В итоге 19 марта 1717 г. Август II отправил Михаилу Коцеллу письмо, в котором выражал удивление по поводу постоянной задолженности государственной казны в отношении Завиши. Монарх пригрозил подскарбию неблагоприятными последствиями за такое поведение ${ }^{24}$.

Но даже это не помогло решить конфликт, и 10 мая 1717 г. Кшиштоф Завиша жаловался Михаилу Шумскому (подстолий и подвоевода Минского воеводства в городском управлении), что многократно требовал у Михаила Коцелла с помощью влиятельных высокопоставленных друзей выплаты обещанной суммы. Тем не менее вышеупомянутый Коцелл и пальцем не пошевелил, чтобы вернуть ему деньги ${ }^{25}$

Датируемая 23 июня 1717 г. запись из главных трибунальских книг в Вильне подтверждает поступление дела в трибунал. От имени Завиши участвовать в заседаниях должен был Михаил Копеть, ошмянский староста. Патроном Коцелла выступал Андрей Ходзько, ошмянский обозный. Однако дело было отложено на другой срок, под документом проставлена виленская земская печать ${ }^{26}$.

В начале осени 1717 г. Михаил Коцелл получил повестку в суд с требованием явиться в течение четырех недель. Письмо было доставлено «обжа- лованному» 9 сентября и вручено в присутствии Яна и Стефана Завадских с немедленным ответом. Через две недели, 24 сентября, Завиша расписался в получении 804 тымфов, пересланных литовским подскарбием ${ }^{27}$. На этом выплаты остановились.

Следует добавить, что весь 1717 г. минский староста был в хороших отношениях с Огинскими и стремился завоевать расположение короля. Своего сына Игнатия он отправил в Саксонию, в военную школу и на королевскую службу. Также в этот период Завиша путешествовал вместе с Иосифом Огинским [1, s. XXXIII].

В 1718 г. Завиша записал: «В Минске этот год я начал, следя за делами трибунала, но мало выиграл, много потеряв» $[1$, s. 166-167]. В том же году, несмотря на активные протесты, отказ в праве заседать в сейме из-за умерщвления свояка, Кшиштоф Завиша все же получил булаву маршалка на гродненском сейме [3, s. 318]. Дело о его деньгах снова набрало ход: 25 августа 1718 г. Тереза Завиша расписалась в получении у подскарбия 373 тымфов, 15 грошей ${ }^{28}$. А 11 ноября Коцелл приказал Яну Шреттеру выплатить Кшиштофу Завише 500 талеров. На обратной стороне письма имеется подпись минского старосты, подтверждающая получение им этой суммы ${ }^{29}$. Документ хранится в папке № 515 в сборниках Научной библиотеки Польской академии искусств и Польской академии наук в Кракове.

\section{Заключение}

Из изученного архивного материла невозможно определить точно, получил ли Завиша 4 тыс. талеров, обещанные ему Августом II. Многие годы борьбы за их выплату указывают, что получение, по крайней мере, части этой суммы стоило минскому старосте больших усилий и средств. Кроме того, протяженность этих мероприятий во времени свидетельствует о накале спора между Кшиштофом Завишей и Михаилом Коцеллом, его главным оппонентом в борьбе за деньги. Рассматриваемые со- бытия подтверждают также, что в данной ситуации поддержки короля, который, казалось бы, стоял на стороне Завиши, оказалось недостаточно. Однако неизвестно, насколько искренними являлись усилия Августа II, принимая во внимание тот факт, что минский староста не был лояльным по отношению королю. Этот спор, как и вся общественная деятельность Кшиштофа Завиши, вписывается в политическую борьбу, проходившую в Великом княжестве Литовском в начале XVIII в.

\section{Библиографические ссылки / References}

1. Zawisza K. Pamiętniki Krzysztofa Zawiszy, wojewody mińskiego (1666-1721), wydane z oryginalnego rękopismu i opatrzone przypiskami przez Juliana Bartoszewicza. Warszawa: [s. n.]; 1862. LXXIII, 440 s.

2. Rachuba A. Sapieha Benedykt Paweł. W: Polski słownik biograficzny. Tom 34. Wrocław: Zakład narodowy im. Ossolińskich; 1992-1993. s. 583-591.

3. Sliesoriūnas G. Lietuvos didžioji kunigaikštystè vidaus karo išvakarèse: didiku grupuočių kova 1690-1697 metais. Vilnius: LII leidykla; 2000. 346 p.

\footnotetext{
${ }^{24}$ List Augusta II do Michała Kotła (sic!), Warszawa, 19.03.1717 // BPAN. Ms. 5915. K. 28 r.

${ }^{25}$ Skarga Krzysztofa Zawiszy starosty mińskiego do Michała Rafała Szumskiego podstolego i podwojewodziego województwa wileńskiego w urzędzie grodzkim na Michała Kotła podskarbiego Wielkiego Xięstwa Litewskiego, Wilno, 10.05.1717 // Ibid. K. 29 r. $29 \mathrm{v}$.

${ }^{26}$ Wypis z Xiąg Głównych Trybunalskich w Wilnie odprawowany, 17.06.1717 // Ibid. K. 30 r. - 31 r.

${ }^{27}$ August II do Michała Kociełła, [b. m.], 9.09.1717 // Ibid. K. 32 r. - 32 v.

${ }^{28}$ Kwit Teresy Zawiszyny wystawiony Michałowi Kociełłowi, Wilno, 25.08.1718 // Ibid. K. 34 r.

${ }^{29}$ Kwit Krzysztofa Zawiszy wystawiony Michałowi Kociełłowi, [b. m.], 13.09.[?] // Ibid. K. 35 r. - 35 v.
} 
4. Staszewski J. «Jak Polskę przemienić w kraj kwitnacy...». Szkice i studia z czasów saskich. Olsztyn: Ośrodek Badań Naukowych im. Wojciecha Kętrzyńskiego w Olsztynie; 1997. 275 s.

5. Volumina legum. Przedruk zbioru praw staraniem XX. Pijarów w Warszawe, od roku 1732 do roku 1782, wydanego. Tom 5. Petersburg: [s. n.]; 1860.463, XV s.

6. Staszewski J. August II Mocny. Wrocław: Ossolineum; 1998. $316 \mathrm{s.}$

7. Dybaś B. Sejm pacyfikacyjny w 1699 r. Toruń: Towarzystwo Naukowe w Toruniu; 1991. 274 s

8. Nycz M. Geneza reform skarbowych sejmu niemego: studium z dziejów skarbowo-wojskowych z lat 1697-1717. Poznań: Poznańskie Towarzystwo Przyjaciół Nauk; 1938. 311 s.

9. Staszewski J. «Postanowienie wileńskie» z 1701 r. i jego wpływ na unię polsko-litewską w czasach saskich. Zapiski Historyczne. 1986;51(1):83-96.

10. Kowecki J. Kociełł Michał Kazimierz. W: Polski słownik biograficzny. Tom 13. Wrocław: Zakład narodowy im. Ossolińskich; 1967-1968. s. 223-225.

11. Sowa A. Pociej Ludwik Konstanty. W: Polski słownik biograficzny. Tom 27. Wrocław: Zakład narodowy im. Ossolińskich; 1983. s. 38-47.

12. Gierowski JA. Traktat przyjaźni Polski z Francją w 1714 r. Warszawa: PWN; 1965. 299 s.

13. Michalski J. Sejm w czasach saskich. W: Michalski J, redaktor. Historia sejmu polskiego. Tom 1. Do schyłku szlacheckiej Rzeczypospolitej. Warszawa: Państwowe Wydawnictwo Naukowe; 1984. s. 300-349.

Статья поступила в редколлегию 04.04.2019. Received by editorial board 04.04.2019. 